\title{
Evaluation of antibacterial activity of Coriandrum sativum ( $L$.) against gram - positive and gram - negative bacteria
}

\author{
D. Sambasivaraju, Fazeel ZA*
}

Department of Pharmacology, Viswabharathi Medical College, Kurnool, AP, India - 518463

Received: 05 October 2016 Accepted: 03 November 2016

\section{*Correspondence to:}

Dr. Fazeel ZA,

Email: fazeel_zubair@ yahoo.com

Copyright: (C) the author(s), publisher and licensee Medip Academy. This is an openaccess article distributed under the terms of the Creative Commons Attribution NonCommercial License, which permits unrestricted noncommercial use, distribution, and reproduction in any medium, provided the original work is properly cited

\begin{abstract}
Background: Most of the present anti-bacterials are either semisynthetic modifications of some natural compound or are synthetic chemicals. All of them have acceptable spectrum of action and efficacy but none of them are devoid of side effects. For this reason a new anti-bacterial is needed which should have same acceptable efficacy with better safety. Coriander (Coriandrum sativum L.) is a well-known herb commonly used in cooking, folk medicine, pharmaceutical and food industries. In this study we have tested anti-bacterial activity of coriander oil against 5 microorganisms and compared the results with ampicillin and genatmicin.
\end{abstract}

Methods: The study was done on five bacteria - Staphylococcus aureus, Escherichia coli, Klebseilla, Pseudomonas and Salmonella. Antibiotic sensitivity testing was done on Mueller Hinton agar plates by Kirby-Bauer disk diffusion method. After application of inoculum antibiotic discs of $2 \mathrm{~mm}$ diameter impregnated with ampicillin, gentamicin or coriander oil were placed $2 \mathrm{~cm}$ apart from each other. Each drug sample was used in triplicate. Incubation was done for $18-24$ hours at $37^{\circ} \mathrm{C}$ aerobically. The diameters of zones of inhibition were measured in $\mathrm{mm}$ and expressed as Mean $\pm \mathrm{SD}$.

Results: Coriander oil expressed highest antibacterial action against E. coli $(10.73 \pm 0.21)$ which was better than Gentamicin $(9.47 \pm 0.45)$. Coriander also inhibited growth of Salmonella $(9.53 \pm 0.40)$ which was slightly less than Ampicillin (10.57 \pm 0.21$)$ and least activity was expressed against Klebsiella (7.20 \pm 0.17$)$ and that also was close to action of Ampicillin (8.43 \pm 0.25$)$.

Conclusions: Coriander oil demonstrated good anti-bacterial activity against commonly five occurring microorganisms but further extensive studies are required to isolate the active ingredient responsible for antibacterial action and develop coriander essential oil as a clinically proven antibacterial agent.

Keywords: Ampicillin, Anti-bacterial, Coriander; E. coli, Gentamicin, Salmonella

\section{INTRODUCTION}

Essential oils of herbs and their components, which are products from the secondary metabolism of plants, have many applications in ethno-medicine, food flavouring, food preservation, cosmetics and pharmaceutical industries. ${ }^{1}$ The antimicrobial properties of essential oils have been described ${ }^{2,3}$ and, because of the growing demand on antimicrobials for preventing microbial food spoilage and bacterial infections, there is an increasing interest in medicinal plants as an alternative to synthetic preservatives and antibiotics. ${ }^{4}$ Many essential oils are already being used in the food industry as flavouring agents and some are known to exert antimicrobial activity, but the mechanism of action is often not entirely understood.

Most of today's antibacterials are either semisynthetic modifications of various natural compounds or are manufactured chemicals. All of them have acceptable spectrum of action, acceptable efficacy but none of them are devoid of adverse effects. Some antibacterials have so severe side effects that risk:benefit ratio needs to be evaluated before administering. ${ }^{5}$ As a result, there is need for newer anti-bacterial which should have atleast same efficacy as the current drugs and better safety profile. Coriander (Coriandrum sativum L.) is a well-known herb widely used as a spice, in folk medicine, pharmaceutical 
and food industries. ${ }^{1}$ Coriander seed oil is one of the 20 major essential oils in the world market ${ }^{2}$ and it is known to exert antimicrobial activity however, its mechanism of action is still unclear. ${ }^{3}$

Our present study is aimed at evaluating antibacterial activity of coriandrum sativum oil against Gram-positive and Gram-negative bacteria.

\section{METHODS}

The present study was conducted at Departments of Pharmacology and Microbiology, Narayana medical college, Nellore. Prior approval from Institutional Ethics Committee was taken. Coriander oil was purchased from Falcon Pharmaceuticals Ltd, Bangalore. Ampicillin (Cipla) and Gentamicin (Cipla) vials were purchased from hospital pharmacy.

Five human pathogenic bacteria were selected for the present investigation - Staphylococcus aureus, Escherichia coli, Klebseilla pneumoniae, Pseudomonas and Salmonella typhi.

Antibiotic sensitivity testing was performed on Mueller Hinton agar plates by Kirby-Bauer disk diffusion method. Five petri dishes separate for each microorganism were used. Lawn culture was done over Mueller Hinton agar. Suspension of organism was matched with $0.5 \mathrm{Mc}$ Farland standards. After inoculums were applied, antibiotic discs of $2 \mathrm{~mm}$ diameter impregnated with ampicillin, gentamicin or coriander oil were placed $2 \mathrm{~cm}$ apart from each other on culture media with sterile forceps. 3 samples of each drug were used. ${ }^{20}$

The plates were incubated for $18-24$ hours at $37{ }^{\circ} \mathrm{C}$ aerobically. The diameters of zone of inhibition of each sample were measured in mm using callipers. Diameters of zone of inhibition of each drug were expressed as Mean \pm SD. The mean of diameter of zone of inhibition produced by coriander oil were then compared with those of standard antibiotics ampicillin and gentamicin ${ }^{6}$.

\section{RESULTS}

Coriander oil demonstrated antibacterial activity like standard antibiotics ampicillin and gentamicin, which could be seen from diameter of zones of inhibition measured in $\mathrm{mm}$ and expressed as Mean $\pm \mathrm{SD}$. The results of bacterial growth inhibition of coriander oil, gentamicin and ampicillin are tabulated in Table 1. Coriander oil expressed highest antibacterial action against E. coli $(10.73 \pm 0.21)$ which was higher than Gentamicin $(9.47 \pm 0.45)$. E. coli was followed by Salmonella $(9.53 \pm 0.40)$ which was slightly less than Ampicillin (10.57 \pm 0.21$)$. Least activity of Coriander was expressed against Klebsiella $(7.20 \pm 0.17)$ but that was quite near to action of Ampicillin (8.43 \pm 0.25$)$. The results of coriander oil have been compared with ampicillin and gentamicin in Figure 1.
Table 1: Comparison of zone of inhibition of coriander oil, ampicillin and gentamicin on different microorganisms.

\begin{tabular}{|llll|}
\hline Test organisms & \multicolumn{3}{l}{ Zone of inhibition (diameter in mm) } \\
& $\begin{array}{l}\text { Coriander } \\
\text { oil }\end{array}$ & Ampicillin & Gentamicin \\
\hline $\begin{array}{l}\text { Staphylococcus } \\
\text { aureus }\end{array}$ & $8.67 \pm 0.32$ & $10.37 \pm 0.30$ & $10.37 \pm 0.25$ \\
\hline E. Coli & $10.73 \pm 0.21$ & $11.37 \pm 0.21$ & $9.47 \pm 0.45$ \\
\hline $\begin{array}{l}\text { Klebsiella } \\
\text { pneumoniae }\end{array}$ & $7.20 \pm 0.17$ & $8.43 \pm 0.25$ & $10.83 \pm 0.12$ \\
\hline Pseudomonas & $8.33 \pm 0.29$ & $11.53 \pm 0.21$ & $9.67 \pm 0.40$ \\
\hline $\begin{array}{l}\text { Salmonella } \\
\text { typhi }\end{array}$ & $9.53 \pm 0.40$ & $10.57 \pm 0.21$ & $12.50 \pm 0.20$ \\
\hline
\end{tabular}

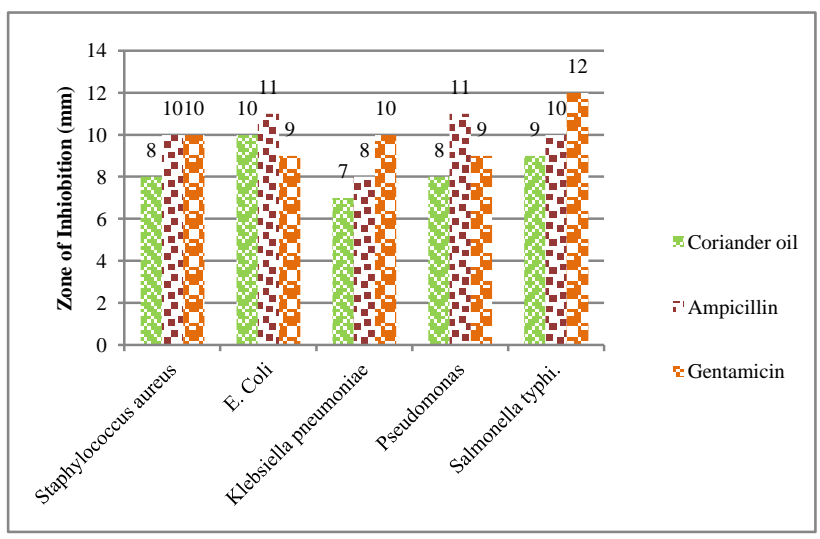

Figure 1: Comparison antibacterial activity of coriander oil, ampicillin and gentamicin on staph. aureus, e. coli, klebsiella, pseudomoas and salmonella.

\section{DISCUSSION}

Microorganisms are the concealed enemies to mankind. They are small but cause profound damage to human body as well as other living organisms. The agents, which have the capacity to kill the microbes or arrest the multiplication, are called antimicrobial agents. There are a lot of antimicrobial drugs of which some are established and some are hidden in nature. Hence, the last decade witnessed an increase in the investigations on plants as a source of human disease management ${ }^{7-9}$ and more natural antimicrobials have driven scientists to investigate the effectiveness of inhibitory compounds such as extracts from plants. ${ }^{10}$ There are several reports for antibiotics resistance of human pathogens to available antibiotics. Biomolecules of plant origin appear to be one of the alternatives for the control of these antibiotic resistant human pathogens. ${ }^{11.12}$

Microbial resistance to antimicrobials is a matter of great importance if sensitive strains are superseded by resistant ones. Then a valuable drug may become useless. Resistance may become more prevalent in a human population by spread of microorganisms containing resistance genes, and this may also occur by dissemination of the resistance genes among different 
microbial species. Antibiotics are the only group of therapeutic agents which can alter the actual diseases suffered by infected individuals by microorganisms. ${ }^{5}$ Problem of antimicrobial resistance have increased during the past decade in most countries of the world. Some resistant microbes are currently mainly restricted to patients in the hospital. E.g. MRSA, Vancomycinresistant enterococci, and coli forms that produce extended spectrum $\beta$ - lactamases. On the other hand there are microbes which infect patients in the community. e.g. Penicillin-resistant Streptococcus pneumonia and multiresistant Mycobacterium tuberculosis. ${ }^{13}$

This study dealt with five common pathogenic bacteria Escherichia coli, Klebsiella pneumoniae, Pseudomonas and Salmonella typhi which are gram negative bacteria and Staphylococcus aureus a gram positive bacteria. All the five human pathogenic bacterial strains were sensitive to essential oil of Coriandrum sativum. Coriandrum sativum essential oil showed highest inhibitory activity against Escherichia coli. The results of coriander essential oil, antibiotic sensitivity test were compared with standard antibiotics ampicillin and gentamicin which were tested against the same above mentioned bacteria in similar conditions. The antibacterial activity of $\mathrm{C}$. sativum against E. coli showed zone of inhibition of $10.73 \pm 0.21 \mathrm{~mm}$ which was higher than gentamicin $(9.47 \pm 0.45 \mathrm{~mm})$ and near to ampicillin $(11.37 \pm 0.21 \mathrm{~mm})$. C. sativum has demonstrated remarkable antibacterial effect against E. coli compared to other microorganisms. Action of C. sativum against other bacteria was also seen and was comparable to ampicillin and gentamicin.

Findings of our study are in accordance with that of Serban ES et al and Suganya $\mathrm{S}$ et $\mathrm{al}^{14,15}$ as they also observed high antibacterial activity of coriander oil against E. coli and significant antibacterial activity against Staph. aureus, Klebsiella pneumoniae, Pseudomonas and Salmonella typhi. ${ }^{14,15}$

Matasyoh JC et $\mathrm{al}^{16}$ explained that the antibacterial activity exhibited by the $C$. sativum leaf oil can be attributed to the synergic effect of the antimicrobial agents present in the oil. The leaf oil contains 44 compounds mostly of aromatic acids of which the major are 2-decenoic acid, E-11- tetradecenoic acid, capric acid, undecyl alcohol and tridecanoic acid. The high concentration of 2-decenoic acid in leaf oil makes it potentially useful in medicines and perfumes. ${ }^{16}$

Rajeshwari and Andallu ${ }^{17}$ reported that Coriander seeds contain petroselinic acid, linoleic acid, oleic acid and palmitic acid. Major components of essential oil are linalool, a-pinene, camphor and geraniol. They have demonstrated that these contents of coriander (also called cilantro) have some anti-bacterial action against Salmonella which is a frequent and at times lethal cause of food poisoning and the activity of these compounds is comparable with gentamicin. ${ }^{17}$ In our study also, coriander oil showed higher anti-bacterial activity against
Salmonella typhi but next only to E. coli. Our study also demonstrated anti-bacterial activity against Salmonella after E. coli.

Msaada $\mathrm{K}$ et al ${ }^{18}$ stated that Coriander seeds have beneficial effects on health and have high reputation on the list of the healing spices. In India, it is used for its anti-inflammatory properties in folk medicine. ${ }^{19}$ In certain parts of Europe, coriander is traditionally referred as "anti-diabetic" plant. In United States of America, coriander has recently been studied for its cholesterol lowering effects.

Our results showed that, in general, Gram-positive bacteria are less susceptible than Gram-negative bacteria to coriander oil. In various studies conducted it was evident that essential oil of C. Sativum has less activity against Gram +ve mainly Staphylococcus aureus as compared to Gram -ve organisms. Further studies are needed to isolate the active compounds to study for their stability, Pharmacokinetic properties and adverse effects. If proved safe then C. Sativum could be an effective antibacterial compounds for its action against many Gram +ve and Gram -ve organisms.

\section{CONCLUSION}

Coriander (coriandrum sativum L.) essential oil showed apparently significant antibacterial activity against gram negative microorganisms (Escherichia coli, Klebsiella pneumoniae, Pseudomonas and Salmonella typhi) and also gram positive bacteria (Staphylococcus aureus). Further extensive studies are required to isolate and standardize the active phytoconstituent(s) responsible for antibacterial action and develop coriander essential oil as a clinically proven antibacterial agent.

\section{ACKNOWLEDGEMENT}

We express our gratitude to Department of Microbiology, Narayana medical college for providing us the necessary material and allowing us to use their laboratory. We also extend sincere thanks to Professor and HOD, Department of Pharmacology, Narayana medical college for guiding us throughout the research work.

\section{Funding: No funding sources \\ Conflict of interest: None declared \\ Ethical approval: The study was approved by the Ethics Committee}

\section{REFERENCES}

1. Momin AH, Acharya SS, Gajjar AV. Coriandrum sativum- review of advances in phytopharmacology. International Journal of Pharmaceutical Sciences and Research 2012;3(5):1233-39.

2. Lawrence BM. A planning scheme to evaluate new aromatic plants for the flavor and fragrance 
industries. In: Janick J, Simon JE (eds). New crops. New York, Wiley; 1993. pp. 620-27.

3. Burdock GA, Carabin IG. Safety assessment of coriander (Coriandrum sativum L.) essential oil as a food ingredient. Food Chem. Toxicol. 2009;47:22-34.

4. Kanimozhi D, Ratha Bai V, Baskaran C. Evaluation of Anti Microbial Activity of Acalypha indica. International Journal of Research in Pharmacy and Science. 2012;2(1):129-37.

5. Gumbo T. General Principles of Antimicrobial Therapy. In: Brunton LL, Chabner BA, Knollman BC, editors. Goodman and Gilman's The Pharmacological Basis of Therapeutics. 12th ed. New York: Mc Graw Hill; 2011. pp. 1365-78.

6. Wikler MA, Cockerill FR, Craig WA, Dudley MN, Eliopoulos GM. Performance standards for antimicrobial disk susceptibility tests; Approved standard. 9th ed. USA: Clinical Laboratory Standards Institute; 2006:1-30.

7. Vuorelaa P, Leinonenb M, Saikkuc P, Tammelaa P, Rauhad JP, Wennberge T, et al. Natural products in the process of finding new drug candidates. Current Medicinal Chemistry. 2004;11(11):1375-89.

8. Aiyelagabe OO. Antibacterial activity of Jatropa multifida roots. Fitoterapia. 2001;72(5): 544-6.

9. Mishra AK, Dubey NK. Evaluation of some essential oils for their toxicity against fungi causing deterioration of stored food commodities. Appl Environ Microbiol. 1994;60:1101-05.

10. Mounishwamy V, Davimans S, Gunasekaran R. Antibacterial activity of Gossyptein isolated from Hibiscus saddriffa. The antiseptic. 2002;99:81-2.

11. Fabian D, Sabol M, Domaracka K, Bujnakova D. Essential oils - their antimicrobial activity against Escherichia coli and effect on intestinal cell viability. Toxicol In Vitro. 2006;20(8):1435-45.
12. Woldemichael GM, Watchter G, Sing MP. Antibacterial activity of essential oil from Coriandrum Sativum. Journal of Natural products. 2003;66:242-6.

13. Farrington M. Chemotherapy of infections. In: Bennet PN, Brown MJ, Sharma P, editors. Clinical Pharmacology. 11th ed. China: Churchill Livingstone Elsevier. 2012:162-72.

14. Serban ES, Ionescu M, Matinca D, Maier C, Bojita MT. Screening of the antibacterial and antifungal activity of eight volatile essential oils. Farmacia. 2011;59(3):440-6.

15. Suganya S, Bharathidasan R, Senthilkumar G, Madhanraj P, Panneerselvam A. Antibacterial activity of essential oil extracted from coriandrum sativum and GC-MS analysis. Journal of chemical and Pharmaceutical Research. 2012;4(3):1846-50.

16. Matasyoh JC, Maiyo ZC, Ngure RM, Chepkorir R. Chemical composition and antimicrobial activity of the essential oil of Coriandrum sativum. Food Chemistry. 2009;113(2):526-9.

17. Rajeshwari U, Andallu B. Medicinal benefits of coriander. Spatula DD. 2011;1(1):51-8.

18. Msaada K, Hosni K, Taarit MB, Chahed T, Kchouk ME, Marzouk B. Changes on essential oil composition of coriander (Coriandrum sativum L.) fruits during three stages of maturity. Food Chem. 2007;102:1131-4.

19. Reddy LJ, Jalli RD, Jose B, Gopu S. Evaluation of antibacterial and DPPH radical scavenging activities of the leaf extracts and leaf essential oil of Coriandrum sativum linn, World Journal Of Pharmaceutical Research. 2012;1(3):705-16.

20. Winn WC, Koneman EW. Koneman's Color Atlas and Textbook of Diagnostic Microbiology. 6th ed. New Delhi: Lippincott Williams and Wilkins; 2006:975-90.

Cite this article as: Sambasivaraju D, Fazeel ZA. Evaluation of antibacterial activity of Coriandrum sativum (L.) against gram - positive and gram negative bacteria. Int J Basic Clin Pharmacol 2016;5:2653-6. 